\title{
Professor Samuel Julius Gould (13 October 1924-4 December 2019), Emeritus Professor of Sociology, University of Nottingham
}

\author{
Rosalind Jones \\ Formerly managing editor, Government and Opposition
}

(First published online 2 February 2021)

It is with sadness that we mark the death of Julius Gould, who was the last survivor of the group of scholars who founded the journal Government and Opposition, the first issue of which appeared in 1965 . This seems the right moment to recall how it began.

Nearly all of the group had rooms on the same corridor at the London School of Economics in the early 1960s, before Julius left in 1964 to take up his Chair at Nottingham. In his retirement Julius was a regular visitor to the office at the LSE where I arrived as editorial assistant in 1979, so we became quite well acquainted. He took a close interest in the list of forthcoming articles on the blackboard and had an acerbic wit, especially on the subject of academics whose main aim was promotion ('he would sell his grandmother for a Chair'). Julius could also turn the satire on himself; when asked what would be his dream job he replied, 'head of the CIA'. He was amused by, while appreciative of, the buccaneering spirit of Ghiță Ionescu. In those early days the Ionescus, the Goulds and the Schapiros also lived near to each other in Highgate and the early meetings to arrange setting up a company took place in someone's flat under the guidance of Mr Baggot, an accountant who was mildly suspicious of so many foreign names.

Leonard Schapiro, in his Foreword to the first issue, published in 1965, set out its aspirations: it was not intended as another journal of political science, rather

one of the main justifications for our existence will prove to be in the fact that we have set ourselves a strictly interdisciplinary approach to the problem of government and opposition. Historians, sociologists and political scientists will cooperate (I think for the first time) to produce the contents of this journal.

He also expressed the hope that the publication would reach a wider circle of readers 'than would normally be the case in a journal devoted solely to politics'. In a nutshell, the aim was to be interdisciplinary (hence the need for the participation of sociologist Julius Gould) and to appeal to the non-specialist - the informed general reader. (Some present readers might find this surprising.)

(c) The Author 2021. Published by Government and Opposition Limited and Cambridge University Press 
The founding triumvirate were Ghiță Ionescu, sole editor until 1980, who was then a researcher at the LSE and author of, among other books, the prophetic The Break-up of the Soviet Empire (he had also worked as a journalist in Romania and retained a journalistic flair), Isabel de Madariaga, an historian specializing in Russia, and her then husband, Leonard Schapiro, who was a professor at the London School of Economics. Dr de Madariaga had worked on the Slavonic Review and therefore brought practical experience of running a journal. Professor Schapiro was able to secure some support from the LSE - the journal had an office there until 2003. It was the enthusiasm and driving force of Ghiță Ionescu above all which inspired them. Julius Gould told the present writer that Ghiță Ionescu's conviction of the importance of the project was such that he tried to convince him that his (Gould's) participation would be a central concern in his intellectual life. Even if this did not turn out to be literally true, Ionescu's dedication could be infectious and, combined with his love of travel, was crucial in commissioning articles from international scholars of distinction.

The Government and Opposition Annual Lecture was inaugurated at the LSE in 1980 and Julius and his wife June attended regularly. (Julius was one of those who suggested renaming it the Government and Opposition/Leonard Schapiro Lecture following Leonard's death in 1984 and it remains a highlight of our year.) My husband and I enjoyed the company of Julius and June at receptions and dinners that followed, and Cedric mentioned that he thought he had an ancestor by the name of Benjamin who had lived in the Cardiganshire hills. At the next chance meeting Julius said that he had looked up the name in a Jewish history archive and that the Benjamins were probably tinkers who had migrated hundreds of miles to get to Wales.

Julius Gould continued to attend meetings of the Board of Directors of Government and Opposition Limited well into old age when his sight was already failing. There were times when he appeared to have fallen asleep but would wake up and contribute an apposite comment.

Cite this article: Jones R (2021). Professor Samuel Julius Gould (13 October 1924-4 December 2019), Emeritus Professor of Sociology, University of Nottingham. Government and Opposition: An International Journal of Comparative Politics 56, 383-384. https://doi.org/10.1017/gov.2020.35 